\title{
PENGGUNAAN MEDIA SOSIAL INSTAGRAM HALOA CAFE SEBAGAI KOMUNIKASI PEMASARAN ONLINE
}

\author{
Nurul Rizky ${ }^{1}$ Sri Dewi Setiawati ${ }^{2}$ \\ ${ }^{1,2}$ ARS University Bandung \\ 1dyn.rzky10@gmail.com, 2dewi@gmail.com
}

\begin{tabular}{l}
\hline \hline Article Info \\
\hline Article history: \\
Received 11 Agustus 2020 \\
Accepted 5 September 2020 \\
Published 1 Oktober 2020 \\
\hline
\end{tabular}

Keyword:

Komunikasi Pemasaran,

Media Baru, Instagram

\section{Abstract}

The rapid development of business today has resulted in increasingly fierce competition. Not only how a business provides products and services but how the products and services that have been produced can be accepted, known, by consumers. Marketing communications today can be done anywhere and anytime due to technological advances such as social media. In this study the researcher aimed to find out how the Haloa Cafe's marketing strategy through social media Instagram, in this study using the new media theory. The method used is a case study with a qualitative approach. The result of this research is that Haloa Cafe chooses social media Instagram as the main marketing tool in social media. This is attributed to the increasing number of Instagram social media users and in accordance with the marketing target of Haloa Café.

Pesatnya perkembangan bisnis saat ini mengakibatkan persaingan semakin sengit. Bukan hanya bagaimana suatu bisnis menyediakan produk dan layanan tetapi bagaimana produk dan jasa yang telah dihasilkan untuk dapat diterima, diketahui, oleh konsumen. Komunikasi pemasaran dewasa ini mampu dilakukan dimana saja dan kapan pun dikarnakan oleh kemajuan teknologi seperti contoh media sosial. Dalam penelitian ini peneliti bertujuan untuk mengetahui bagaimana strategi pemasaran Haloa Cafe melalui media sosial instagram, dalam penelitian ini menggunakan teori media baru. Metode yang digunakan pun yaitu studi kasus dengan pendekatan kualitatif. Hasil dalam penelitian ini yaitu Haloa Cafe memilih media sosial instagram sebagai alat pemasaran utama di media sosial. Hal ini dikarnakan oleh pengguna media sosial instagram yang semakin meningkat dan sesuai dengan target pemasaran Haloa Cafe.

\section{Editorial Office:}

Program Studi Ilmu Komunikasi, Fakultas Dakwah dan Komunikasi, UIN Sunan Ampel Surabaya. Jl. Ahmad Yani 117 Surabaya, Jawa Timur, Indonesia.

Email: jurnalilkom@uinsby.ac.id 


\section{Pendahuluan}

Seiring dengan berkembangnya zaman, berkembangnya teknologi informasi mampu memudahkan manusia untuk beraktifitas, mendapatkan berita maupun mencari berbagai informasi yang beredar di dunia maya. Pesatnya perkembangan teknologi informasi kini dapat mempengaruhi hampir seluruh aspek kehidupan. Media internet bukan lagi sesuatu hal yang baru dalam kehidupan saat ini. Kehadiran internet seakan-akan menghilangkan batas jarak dan waktu untuk memperoleh informasi. Setiap orang juga dapat berkomunikasi dengan orang lain dimana pun dan kapan pun. Secara teknis internet merupakan perpaduan antara komputer, telekomunikasi dan media dalam bentuk digital.

Perkembangan teknologi banyak mempengaruhi berbagai aspek kehidupan salah satunya perdagangan, dampak yang di timbulkan pun dapat menyebabkan semakin memperluasnya perdagangan bebas seakan perdagangan menjadi tidak terbatas ruang dan waktu. Hal ini yang menyebabkan semakin tingginya persaingan yang harus di hadapi oleh semua pihak, terutama pihak perusahaan selaku produsen. Perusahaan pun pada akhirnya harus jeli menentukan strategi pemasaran produknya agar dapat dipercaya dan dipilih konsumen. Perumusan strategi pasar dan pemahaman akan situasi pasar yang tepat akan membantu perusahaan untuk memenangkan persaingan pasar. Salah satu strategi yang harus dilakukan

1 Bulaeng, A.R., Komunikasi Pemasaran. (Jakarta: Universitas Terbuka, 2002), 15. adalah dengan promosi yang merupakan salah satu unsur pemasaran.

Dalam dunia bisnis strategi pemasaran atau strategi marketing sangat diperlukan oleh suatu perusahaan. Tujuannya agar produk atau jasa yang akan ditawarkan dapat bersaing dengan kompetitor lain. Menurut Bulaeng A.R strategi komunikasi pemasaran adalah sebagai satu awal untuk mengenalkan produk kepada konsumen yang sangat penting, karena berkaitan dengan keuntungan yang akan diperoleh penjual. Dalam sebuah komunikasi pemasaran produk baik melalui online maupun pemasaran langsung, strategi komunikasi sangatlah perlu dilakukan. ${ }^{1}$ Sementara Djaslim Saladin berkata, Komunikasi pemasaran adalah suatu kegiatan yang berusaha untuk menyebarkan informasi, yang dapat mempengaruhi, membujuk dan mengingatkan bahwa target pasar atas produk dan perusahaannya supaya bersedia menerima, membeli loyal terhadap produk yang ditawarkan oleh perusahaan yang bersangkutan. $^{2}$ Dalam hal ini, upaya perusahaan menjaga loyalitas konsumen adalah hal penting yang harus dilakukan. Seperti yang dikatakan Kotler Karna loyalitas tidak mungkin hadir begitu saja, diperlukan strategis dalam pengolahan konsumen guna memperolehnya. Strategi komunikasi pemasaran dapat dilakukan dengan periklanan, promosi penjualan,

2 Saladin, D., Manajemen Pemasaran, Analisis, Perencanaan, Pelaksanaan, dan Pengendalian. Bandung: Lindakarya, 2001), 23. 
personal selling, direct marketing dan public relations. ${ }^{3}$

Kemunculan New Media atau Internet saat ini telah dianggap sebagai kebutuhan utama dalam perusahaan modern, hal itu bertujuan untuk melaksanakan kegiatan promosi pemasaran. Proses pemasaran saat ini tidak luput dari penggunaan dan pemanfaatan teknologi, terutama media sosial yang saat ini banyak digunakan oleh para praktisi bisnis, Salah satunya Instagram yang merupakan layanan microblogging dan jejaring sosial internet, yang mampu tumbuh secara pesat. Menurut Knibbs dalam, ${ }^{4}$ akun Instagram perusahaan yang memiliki postingan dengan gambar dan video menarik, memiliki peluang untuk membuat umpan balik yang positif. Bila didefinisikan Instagram adalah salah satu media berkumpulnya jutaan orang secara maya setiap harinya. Maka dari itu potensi untuk melakukan praktek pemasaran dan promosi berpotensi sangat besar. Instagram sangat berpotensi untuk dimanfaatkan sebagai media promosi dan marketing sebuah jasa, produk atau branding perusahaan. Menurut data yang dirilis Napoleon Cat dalam Mustafa Imam, pada periode Januari-Mei 2020, pengguna Instagram di Indonesia kini mencapai 69,2 juta (69.270.000) pengguna. Pencapaian itu merupakan suatu peningkatan dari bulan - bulan sebelumnya terhadap penggunaan di platform berbagi foto dan

${ }^{3}$ Kotler, P., Manajemen Pemasaran Analisis, Perencanaan, Implementasi, dan Control, (Jakarta: PT Prenhalindo, 1997), 19.

${ }^{4}$ Rochman, E. A., \& Iskandar, B. P., Users' engagement toward the brand accounts in instagram based on the aisas model. Journal of business and management 4 no.8 (2015), 890-900. video ini. Pada bulan Januari sudah tercatat sekitar 62,23 juta pengguna instagram, lalu naik pada bulan Februari mencapai 62,47 juta penggunaan. Kemudian di bulan selanjutnya (Maret) jumlah penggunanya terus membeludak dan mencapai 64 juta pengguna. $^{5}$

Kota Bandung sebagai salah satu kota perdagangan dan jasa yang mengalami perkembangan bisnis yang cukup pesat di Indonesia, Bandung merupakan tempat yang strategis dan menguntungkan bagi para pelaku bisnis, baik bisnis melalui media konvensional ataupun media online. Seperti di lansir oleh Wikipedia Pada awalnya kota Bandung dan sekitarnya secara tradisional merupakan suatu kawasan pertanian, tetapi seiring dengan lajunya urbanisasi menjadikan lahan pertanian berubah menjadi kawasan perumahan serta kemudian berkembang menjadi kawasan perindustrian dan bisnis, seperti transformasi ekonomi kota pada umumnya. Saat ini sektor perdagangan dan jasa memainkan peranan yang begitu penting dalam pertumbuhan ekonomi kota ini. Disamping terus meningkatnya perkembangan di sektor industri, Selain itu kota Bandung pun dikenal sebagai salah satu kota belanja, dengan factory outlet dan mall yang kian banyak tersebar di penjuru kota ini, dan saat ini mulai berangsurangsur kota Bandung menjadi kota wisata

5 Mustafa, I., Pengguna Instagram di Indonesia Didominasi Wanita dan Generasi Milenial, Juni 14, 2020), https://www.goodnewsfromindonesia.id/2020/06/1 4/pengguna-instagram-di-indonesia-didominasiwanita-dan-generasi-milenial 
kuliner. ${ }^{6}$ Menyadari hal itu, banyak pihak yang pada akhirnya memilih untuk ikut serta dalam perdagangan dan jasa khususnya melalui media sosial instagram. Akun-akun instagram mulai banyak digunakan bukan hanya sekedar sarana penyampai informasi pribadi saja, tetapi juga digunakan sebagai alat utama dalam pemasaran, promosi dan sebagai akun bisnis.

Salah satu perusahaan yang saat ini mempergunakan media sosial instagram sebagai alat promosi dan akun bisnis yaitu Haloa Cafe. Dalam penjelasannya Haloa Cafe adalah salah satu perusahaan yang saat ini bergerak di bidang food \& beverage dengan konsep coffee shop, awal berdirinya Haloa Cafe pada 11 November 2019, mendeklarasikan dirinya sebagai pendatang baru didunia bisnis. Permasalahan utama saat ini yang dihadapi Haloa Cafe sebagai pendatang baru dalam bidang ini yaitu harus memiliki strategi dalam menghadapi pesaing-pesaing lain, karna Coffee shop di kota Bandung kini kian berjamur yang mengharuskan Haloa Cafe untuk mampu menempatkan diri sebagai coffee shop yang mampu di percaya agar dapat memperoleh loyalitas dari pelanggan. berdasarkan pembahasan di atas permasalahan dalam penelitian ini dapat dirumuskan sebagai berikut "Bagaimana strategi komunikasi pemasaran Haloa Cafe melalui media sosial instagram dalam menghadapi persaingan bisnis".

6 Wikipedia Ensiklopedia Bebas Kota Bandung, Wikipedia, Agustus 6, 2020, https://id.wikipedia.org/wiki/Kota_Bandung\#Perek onomian

\section{Kajian Pustaka}

\section{Komunikasi Pemasaran}

Komunikasi pemasaran dapat di simpulkan sebagai suatu kegiatan dimana sebuah komunikasi yang dilakukan oleh suatu perusahaan untuk menyampaikan pesan kepada konsumen dan pelanggannya. Tujuannya agar mampu mendapatkan hasil suatu produk. Dalam kegiatan pemasaran, komunikasi merupakan suatu pemasaran agar perencanaan strategi tercapai atau berhasil sesuai dengan apa yang diinginkan. Komunikasi yang efektif sangat di perlukan supaya kegiatan pemasaran berjalan dengan baik.

Menurut Tjiptono yang dimaksud komunikasi pemasaran adalah aktifitas pemasaran yang berusaha untuk menyebarkan informasi, mempengaruhi, membujuk, mengingatkan para sasaran atas produk dan perusahaannya agar bersedia membeli, menerima, dan loyal terhadap produk yang di tawarkan. ${ }^{7}$ Definisi dasar komunikasi pemasaran ialah proses manajemen di mana organisasi masuk untuk dapat melakukan komunikasi kepada berbagai elemen masyarakat. Komunikasi pemasaran merupakan suatu promosi dari organisasi mengenai apa yang di tawarkan dan agar mampu memberi sebuah makna tentang tindakan dalam proses pemasaran yang akan berdampak pada pemikiran konsumen.

7 Tjiptono, F., Strategi Pemasaran, ed. 3, (Yogyakarta: ANDI. (2008), 54. 


\section{Konsep Pemasaran}

Dalam proses komunikasi pemasaran dibutuhkan adanya suatu konsep pemasaran. Menurut Kotler dalam (Aprilya, 2017) ada 4 fungsi konsep pemasaran yang dikenal dengan $4 \mathrm{P}$ antara lain product, place, price, dan promotion. ${ }^{8}$ Beberapa penjabaran mengenai konsep 4P tersebut, secara spesifik dapat dijelaskan sebagai berikut.

\section{a. Product (Produk)}

Product merupakan suatu benda maupun jasa yang akan ditawarkan ke pasar untuk dilihat, disentuh, dipegang, diperoleh, dibawa dan digunakan serta dikonsumsi untuk mampu memenuhi kebutuhan dan keinginan suatu individu maupun kelompok. Produk juga terdiri dari berbagai macam, kualitas, fitur, desain, nama merek, pengemasan, ukuran, serta layanan.

b. Price (Harga)

Price merupakan penetapan nominal uang yang harus dibayar oleh konsumen ketika ingin membeli suatu produk atau untuk melakukan pertukaran hak milik produk tersebut. Harga meliputi harga terakhir, diskon atau potongan harga, tunjangan, periode pembayaran, persyaratan kredit, dan juga harga eceran.

\section{c. Place (Tempat)}

Place secara umum dipahami sebagai sebuah lokasi, ruang, atau tempat yang

\footnotetext{
${ }^{8}$ Aprilya, T., Strategi Komunikasi Pemasaran Melalui Instagran Dalam MeningkatkanKepercayaam Customer Di Samarinda, eJournal Ilmu Komunikasi, (2017). 67.
}

berguna dan menguntukan perusahaan untuk memberikan kemudahan konsumen dalam menjangkau untuk memperoleh produk, sehingga tempat atau lokasi haruslah strategis untuk membuat produk yang dihasilkan atau dijual, terjangkau dan tersedia di pasaran. Tempat juga meliputi unsur saluran, cakupan, assortment, lokasi, inventaris, dan transportasi.

\section{d. Promotion (Promosi)}

Kegiatan pemasaran dalam memberikan informasi persuasif yang menarik mengenai produk yang ditawarkan oleh penjual ataupun produsen. Aktivitas ini dapat dilakukan secara langsung atau melalui pihak yang menjadi perantara yang dapat mempengaruhi pembelian. Tujuan dari promosi adalah untuk mengidentifikasi dan menarik konsumen baru, menginformasikan adanya produk baru, meningkatkan jumlah konsumen, memberitahukan kepada konsumen tentang adanya pengembangan dan peningkatan kualitas produk yang ditawarkan, mengajak konsumen untuk mendatangi tempat atau lokasi penjualan produk, serta memberikan motivasi kepada konsumen agar membeli dan memilih produk yang ditawarkan.

Untuk melakukan promosi dibutuhkan suatu konsep mendasar. Seperti yang 
dijabarkan diatas oleh Kotler, apabila produsen telah memenuhi syarat dalam konsep tersebut, akan menjadikan penilaian baik untuk memulai tahap promosi yang bertujuan menarik minat konsumen.

\section{Pengertian Strategi}

Pengertian strategi menurut Stoner, Freeman, dan Gilbert, Jr. (1995) dalam (Tjiptono, 2008) di definisikan sebagai dua prespektif yang berbeda, yaitu satu (1) dari prespektif mana organisasi ingin lakukan yaitu (intends to do), dan dua (2) dari perspektif apa organisasi yang akhirnya dilakukan (eventually does). ${ }^{9}$ Berdasarkan prespektif yang pertama, strategi dapat difenisikan sebagai suatu program untuk menentukan dan mencapai suatu tujuan organisasi dan dapat mengimplementasikan misinya. Maksudnya yaitu para manajer memainkan peran yang sangat aktif, rasional dan sadar terhadap merumuskan suatu strategi organisasi. Dalam suatu lingkungan yang selalu mengalami perubahan dan turbulen, pandangan ini lebih banyak diterapkan. Berdasarkan prespektif kedua, strategi tersebut, didefinisikan sebagai respon atau pola tanggapan organisasi terhadap lingkungannya.

Berdasarkan kedua prespektif strategi di atas, dapat didefinisikan sebagai respon atau pola tanggapan organisasi terhadap lingkungannya. Setiap organisasi pasti mempunya strategi, walaupun strategi tersebut tidak dirumuskan dengan cara eksplisit. Pandangan ini pula diterapkan untuk para manajer yang bersifat reaktif, yaitu hanya menyesuaikan diri dan menanggapi lingkungan dengan cara pasif yang manakala dibutuhkan. Pernyataan strategi secara eksplisit sebagai salah satu kunci sebuah keberhasilan dalam menghadapi suatu perubahan lingkungan bisnis. Apabila konsep strategi tidak jelas, maka keputusan yang akan diambil bersifat subyektif atau hanya berdasarkan intuisi belaka dan cenderung mengabaikan keputusan yang lain.

Menurut Kotler ada lima aspek strategi komunikasi pemasaran, yaitu:

a. Periklanan Adalah salah satu cara yang efektif untuk menjangkau para konsumen atau pembeli yang tersebar secara geografis dengan biaya yang rendah untuk disetiap tampilannya. Periklanan mampu digunakan untuk membentuk citra jangka panjang untuk sebuah produk dan mempercepat penjualan.

b. Promosi penjualan merupakan suatu ajakan untuk melakukan suatu transaksi pembelian. Perusahaan menggunakan sebuah alat promosi penjualan untuk dapat menciptakan tanggapan yang lebih cepat dan lebih kuat. Promosi penjualan mampu digunakan untuk mendramatisasikan penawaran suatu produk dan mendorong hasil penjualan yang sedang lesu. Tetapi, pengaruh promosi penjualan biasanya bersifat jangka pendek, dan tidak efektif dalam

9 Tjiptono, F., Strategi Pemasaran, ed. 3, (Yogyakarta: ANDI, 2008), 
membangun preferensi produk jangka panjang.

c. Hubungan Publisitas dan Masyarakat, Daya tarik hubungan masyarakat dan publisitas dilandasi pada tiga sifat khusus, kredibilitas tinggi.

d. Penjualan Personal Adalah suatu alat yang sangat efektif terutama untuk membangun preferensi, tindakan pembeli dan keyakinan. Alasannya yaitu karena penjualan personal apabila dibandingkan dengan periklanan, mempunyai tiga manfaat tiga manfaat sendiri.

Bentuk pemasaran langsung (direct marketing), surat langsung (direct message), pemasaran elektronik, pemasaran lewat telepon. Semuanya mempunyai empat karakteristik. Pemasaran lansung bersifat. ${ }^{10}$

\section{Media Baru (New Media)}

Teori new media adalah sebuah teori yang telah dikembangkan oleh Pierre Levy yang mengartikan bahwa media baru merupakan suatu teori yang membahas tentang perkembangan media konvensional ke arah digital. Dalam teori media baru, memiliki dua pandangan. ${ }^{11}$

1. Pandangan interaksi sosial, yang dapat membedakan suatu media berdasarkan kedekatannya dengan interaksi tatap muka.

2. Pandangan integrasi sosial, merupakan sebauh gambaran

${ }^{10}$ Kotler, P., Manajemen Pemasaran Analisis, Perencanaan, Implementasi, dan Control, (Jakarta: PT Prenhalindo, 1997.

11 Solomon, M. R., Consumer Behavior and Marketing Strategy, (New York: Pearson Prentice 2011), 25. media bukan hanya dalam bentuk informasi, dan interaksi, atau penyebarannya. Tetapi dalam bentuk ritual atau seperti apa manusia menggunakan suatu media sebagai salah satu cara menciptakan masyarakat.

Media bukan hanya suatu instrumen informasi atau cara untuk mencapai sebuah ketertarikan diri, namun mempersatukan kita dalam beberapa bentuk karakter masyarakat dan memberikan kita rasa saling memiliki. Istilah new media lambat laun mulai ramai dan dikenal pada tahun 1980. Dimana dunia komunikasi dan media mulai berbeda karna kemunculan media baru ini, tidak ada batasan pada satu elemen atau sektor tertentu.

\section{Media Sosial}

Media mempunyai peranan penting dalam penyampaian sebuah pesan komunikasi. Media menjadi sarana pengirim pesan kepada penerima pesan dalam suatu proses komunikasi. Media sosial menawarkan suatu bentuk komunikasi yang lebih personal, individual, dan dua arah. Melalui media sosial para produsen dapat mengetahui kebiasaan para konsumen mereka dan dapat melakukan interaksi secara personal, serta mampu membangun keterikatan yang lebih dalam. ${ }^{12}$

12 Puntoadi, D., Menciptakan Penjualan Melalui Social Media, (Jakarta: PT Elex Media Computindo, 2011), 21. 
Media sosial adalah aktivitas, praktek dan kebiasaan diantara beberapa komunitas manusia yang berkumpul secara online untuk membagikan informasi, pengetahuan, dan opini melalui media conversational. Media conversational adalah sebuah aplikasi berbasis web yang memungkinkan penggunaannya untuk membuat, mengirim, dan membagikan sebuah konten dalam bentuk susunan katakata, gambar, video, dan atau audio. ${ }^{13}$

Untuk dapat memudahkan para praktisi media sosial, Regina Luttrell menciptakan The Circular Model of Some yaitu sebuah model untuk melakukan suatu perencanaan komunikasi pada media sosial. 'I would like to introduce such a model for social media planning: the Circular Model of Some for Social Communication--Share, Optimize, Manage, Engage. Didalam model ini terdapat Empat aspek yaitu Sharing, Optimize, Manage, dan Engage yang memungkinkan untuk para praktisi dapat mengembangkan strategi yang solid.

Berikut adalah penjelasan mengenai The Circular Model of Some menurut Regina Luttrell dalam bukunya Social Media:

a. Share: Dimana pemirsa saya? Jenis jaringan apa yang mereka gunakan? Di mana kita harus berbagi konten? Sangat penting bagi praktisi sosial media untuk memahami di mana dan bagaimana konsumen berinteraksi. Ini adalah kesempatan perusahaan untuk menghubungkan, membangun

13 Luttrell, R., How to Engage, Share and Connect, (London: Rowman\& Littlefield, 2015), 35 . kepercayaan, dan mengidentifikasi saluran yang memungkinkan interaksi yang tepat.

b. Optimize: Apakah ada masalah yang perlu ditangani? Jenis konten seperti apa yang harus dibagikan? Apakah kita memiliki orang yang dapat berpengaruh terhadap perusahaan dan pendukung? Di mana kita sedang diperbincangkan dan bagaimana? Mengoptimalkan setiap rekaman percakapan adalah hal yang terpenting. Sebuah plan komunikasi yang kuat yang dioptimalkan dengan sangat baik menghasilkan dampak maksimum pada brand, pesan, dan juga nilai.

c. Manage: Apa pesan yang sesuai dan relevan yang harus kita kelola, ukur dan pantau? Dengan mengatur sistem manajemen media seperti dengan Perusahaan hootsuite dimana dapat terus mengikuti percakapan yang terjadi di real-time, menanggapi konsumen langsung, mengirim pesan pribadi, memantau percakapan, berbagi link dan mengukur keberhasilan/kegagalan. Matriks merupakan bagian integral dalam pengelolaan strategi sosial. Sebagai praktisi kita harus menggambarkan nilai upaya dan melaporkan kembali ke tingkat eksekutif.

d. Engage: Siapa yang harus kita libatkan dan bagaimana? Apakah kita ingin konsumen untuk mengambil sebuah tindakan pada sesuatu yang telah kita bagikan? Apabila demikian, apa yang 
kita inginkan dari mereka? Mengolah strategi engagement adalah hal yang cukup sulit, namun ketika perusahaan menyadari manfaat dari sebuah keterlibatan otentik, hubungan yang tepat dapat dibangun.

\section{Metode Penelitian}

Penelitian ini menggunakan metode penelitian kualitatif, yang memiliki tujuan untuk meringkaskan dan menggambarkan berbagai situasi, kondisi atau fenomena realitas sosial yang ada dan sedang terjadi di masyarakat yang akan menjadi objek penelitian dan berusaha menarik sebuah realitas itu ke permukaan sebagai suatu ciri, sifat, karakter, tanda, model atau gambaran tentang situasi, kondisi, ataupun sebuah fenomena tertentu. ${ }^{14}$

Metode yang digunakan dalam penelitian ini adalah studi kasus sebagai bagian dari penelitian kualitatif. Cresswell mengatakan bahwa menurutnya studi kasus merupakan suatu strategi penelitian dimana di dalamnya penelitian menyelidiki secara cermat suatu program, aktivitas, peristiwa, proses atau sekelompok individu. ${ }^{15}$ Karna peneliti ingin menjelaskan secara detail tentang bagaimana HALOA CAFE menggunakan media sosial Instagram dalam melakukan pemasaran. Dengan metode pendekatan kualitatif, penulis berupaya memperoleh informasi dan data-data secara mendalam, lengkap, dan kredible sehingga mampu memenuhi tujuan penelitian. Dalam penelitian ini pengumpulan data dilakukan

14 Bungin Bungin, Penelitian Kualitatif, (Jakarta: Kencana Prenada Media Group, 2009). 68. dalam rentan waktu selama bulan Mei Juli 2020 dengan sumber data primer dan sekunder. Penelitian ini dilakukan di PT. HALOA GUSTO INDONESIA yang berlokasi di Jalan Cipedes Tengah No.198 Kota Bandung, Jawa Barat. Teknik pengumpulan data yang peneliti digunakan meliputi Observasi, Dokumentasi, dan Wawancara tatap muka dan telepon atau chat untuk mendukung validasi data penelitian.

\section{Hasil dan Pembahasan}

Dalam hasil penelitian akan di uraikan dalam beberapa aspek pembahasan. Hasil penelitian akan dipaparkan dan dianalisa lebih terstruktur dan sistematis mengenai strategi komunikasi pemasaran Haloa Cafe melalui media sosial instagram. Penelitian ini dilakukan di Haloa Cafe dan melakukan pengamatan di media sosial instagram. Peneliti melakukan wawancara dan observasi terhadap pihak yang terkait dalam pemasaran Haloa Cafe, maka peneliti memfokuskan hasil penelitian pada suatu permasalahan yaitu strategi komunikasi pemasaran Haloa cafe melalui media sosial instagram. Dalam hasil penelitian ini penulis akan membahas berdasarkan identifikasi masalah dengan teori-teori yang dikaitkan dari berbagai literatur berdasarkan komunikasi pemasaran dan New Media. Dalam mengolah analisa data, penulis menggunakan konsep The Circular Model of Some yang merupakan model yang diciptakan Regina Luttrell yang dapat

15 Creswell, J. W., Esearch Design: Pendekatan Kualitatif Kuantitatif, dan Mixed, (Yogjakarta: PT Pustaka Pelajar, 2010), 
memudahkan para praktisi media sosial dalam melakukan pemasaran di media sosial. Peneliti akan membagi dalam beberapa aspek hasil penelitian berdasarkan identifikasi masalah pada penelitian ini.

\section{Share}

Berdasarkan hasil wawancara proses share dalam strategi komunikasi pemasaran Haloa Cafe melalui instagram, akan dibagi menjadi 3 tahap seperti latar belakang pemilihan instagram, target market, dan bagaimana cara Haloa Cafe membangun kepercayaan konsumen. Berikut tahapan yang dilakukan dalam proses share:

a. Latar belakang Haloa Cafe menggunakan instagram, sebelumnya Haloa Cafe memiliki akun media sosial lain untuk kegiatan promosinya berupa facebook dan twitter, tetapi kedua akun media sosial tersebut sudah jarang digunakan karena penggunaan facebook dan twitter mulai berkurang peminatnya maka dari itu Haloa Cafe saat ini hanya menggunakan dan aktif memposting di media sosial Instagram.

b. Target market Haloa Cafe yaitu seluruh segment, melihat dari konsep yang diterapkan Haloa Cafe yaitu "Fun, Friendly, and Passionate". namun dalam pemasaran yang dilakukan Haloa Cafe di instagram lebih mentargetkan kalangan anak muda, karena penggunaan instagram cukup besar di kalangan anak muda yang cenderung aktif di media sosial manapun.

c. Dalam membangun kepercayaan konsumen, Haloa Cafe sebagai pihak produsen melakukan beberapa upaya yaitu membuat konten-konten yang mampu menumbuhkan kepercayaan konsumen terhadap perusahaan diantaranya me-repost cerita yang di post oleh konsumen yang berkunjung, mem-post foto kegiatan dan acara yang sedang atau sudah berlangsung di Haloa Cafe.

\section{Optimize}

Dapat di asumsikan optimalisasi adalah suatu proses, melaksanakan suatu program yang telah direncanakan dengan terencana guna mencapai tujuan/target sehingga mampu meningkatkan kinerja secara optimal. Berdasarkan hasil wawancara proses Optimize dalam strategi komunikasi pemasaran Haloa Cafe melalui instagram, akan dibagi menjadi 2 tahap seperti tahapan dalam perencanaan komunikasi, dan optimalisasi pesan. Berikut tahapan yang dilakukan dalam proses Optimize:

a. Dalam tahap perencanaan komunikasi, yang dilakukan Haloa Cafe mulai dari hal yang kecil yaitu dengan memanfaatkan fitur bio yang berada di instgaram agar kegiatan pemasaran di media sosial akan semakin optimal. Mencantumkan gmaps atau lokasi dimana Haloa Cafe berada, 
mencantumkan no telepon yang bisa dihubungin jika ada yang ingin mereservasi tempat atau ingin mengadakan eventnya di Haloa Cafe dan mencantumkan alamat web. Foto makanan dan minuman yang akan di posting harus berkualitas baik dari segi pengambilan gambar dan warna agar yang melihat ingin datang dan mencoba makanan yang tersedia di Haloa Cafe.

b. Dalam tahap pengoptimalisasi media sosial instagram, Haloa Cafe menggunakan konsep brand image dengan memasang watermark di setiap postingan dan menggunakan logo Haloa Cafe sebagai foto profil instagramnya, yang bertujuan konsumen selalu mengingat Haloa Cafe. Dalam mengoptimalisasikan konten di instagram, foto dan caption yang akan di gunakan harus sisesuaikan sebelum di share agar dapat menarik minat konsumen. Waktu dalam mem-posting konten dibagi menjadi 3 waktu pagi, siang, dan sore menjelang malam. Dikarenakan dalam rentan waktu tersebut adalah waktu terbaik untuk mem-posting.

\section{Manage}

Untuk mengelola sebuah akun media sosial diperlukan pengelolaan yang baik dan teratur agar mampu tercapai target dan tujuan dari kegiatan media sosial. Maka dari itu diperlukan konsep dan perencanaan sebelum menggunakan media sosial.
Manajemen berperan penting untuk setiap aktifitas individu maupun kelompok dalam suatu organisasi untuk mencapai tujuan yang diinginkan. Dalam mengelola media sosial dibutuhkan sumber daya manusia, pengetahuan dan keterampilan agar aktivitas mampu menjadi lebih efektif atau mampu menghasilkan tindakan dalam mencapai kesuksesan. Berdasarkan hasil wawancara proses Manage dalam strategi komunikasi pemasaran Haloa Cafe melalui instagram, akan dibagi menjadi 3 tahap seperti Instagram monitoring, evaluasi, dan pengolahan feedback. Berikut tahapan yang dilakukan dalam proses Manage:

a. Dalam tahap monitoring, Haloa Cafe memanfaatkan fitur insight instagram. Media monitoring yang dilakukan mencakup top post, impresi, interaksi, top location, gender, age, dan followers. fitur ini dimanfaatkan dan sangat bermanfaat untuk Haloa Cafe

b. Pada tahap evaluasi Haloa Cafe memanfaatkan insight instagram untuk mengatahui para calon konsumen, posting-an seperti apa yang mereka sukai, waktu rata-rata pengikut menggunakan instagram, rentang usia yang mengikuti, dan mengetahui jumlah kunjungan profil. Pada hasil evaluasi tersebut, Haloa Cafe menjadikan bahan pertimbangan dalam perencanaan dan perbaikan selanjutnya.

c. Pada pengelolaan feedback, Haloa Cafe memiliki admin yang bertugas 
untuk mem-posting promo,event dan informasi tentang Haloa Cafe dan membalas komentar dari followers-nya. Selain itu Haloa Cafe sering melakukan realtime interaksi dengan menggunakan fitur live pada saat mengadakan event.

\section{Engage}

Engage merupakan segala bentuk usaha untuk melibatkan customer untuk ikut terlibat di dalam interaksi emosional diantara perusahaan dan pelanggannya. Karna di dalam bisnis, interaksi dengan pelanggan hanya dianggap sebagai proses, namun tidak sebagai hubungan jangka panjang. Dalam proses engage yang dikemukakan oleh Regina Luttrell bahwa siapa yang harus kita libatkan dan bagaimana caranya? Apakah kita ingin konsumen untuk mengambil tindakan pada apa yang telah dan akan kita bagikan? Jika demikian, apa yang kita inginkan dari mereka? Mengolah strategi engagement merupakan suatu hal yang sulit, akan tetapi ketika perusahaan menyadari manfaatnya dari keterlibatan otentik suatu hubungan yang tepat dapat dibangun. ${ }^{16}$ Berdasarkan hasil wawancara proses Engage dalam strategi komunikasi pemasaran Haloa Cafe melalui instagram melakukan beberapa pendekatan kepada stakeholder yaitu

${ }^{16}$ Luttrell, R., How to engage, share and connect, (London: Rowman \& Littlefield, 2015), 35 . kepada influencers dan audience, seperti:

a. Berdasarkan hasil wawancara, Haloa Cafe tidak memiliki Brand Influencers yang tetap namun Haloa Cafe lebih memilih menggunakan Selebgram sebagai Brand Influencers dengan melakukan Endorse, atau mengundang secara langsung untuk review dan melakukan fitur Live instagram. dengan cara seperti itu para selebgram akan memberikan feedback dengan cara mempromosikan Haloa Cafe di akun instagram miliknya.

b. Audience, Haloa Cafe selalu berusaha untuk menjalin hubungan yang baik dengan pelanggan dan followersnya di instagram. namun untuk saat ini Haloa Cafe masih belum melakukan kegiatan atau event besar dikarenakan situasi saat ini belum memungkinkan. Tetapi Haloa Cafe masih berupaya untuk menjaga engage kepada konsumennya.

\section{Kesimpulan}

Berdasarkan hasil penelitian yang telah di lakukan, dikumpulkan, dianalisis dan diinterpretasikan oleh penulis. Maka dapat di tarik kesimpulan bahwa: Proses Share yang dilakukan Haloa Cafe pada perencanaan komunikasi instagram dilatar belakangin karna kebutuhan pemasaran Haloa Cafe yang masih mengandalkan 
instagram sebagai alat promosi utama, dikarnakan pengguna instagram yang mayoritas anak muda sesuai dengan target sasaran Haloa Cafe saat ini. Halao Cafe sendiri sudah berencana untuk melakukan strategi pemasaran yang lebih luas lagi, dan telah mempersiapkan konten dan event untuk membangun kepercayaan konsumen dengan harapan mampu menarik konsumen lebih banyak lagi. Dalam proses Optimize sebenarnya Haloa Cafe telah memenuhi standar dalam pemasaran media instagram akan tetapi Haloa Cafe masih belum konsisten dan cenderung belum maksimal dalam penggunaan instagram sebagai media promosinya. Proses manage yang dilakukan Haloa Cafe dalam perencanaan komunikasi instagram adalah dengan memanfaatkan insight instagram untuk monitoring, dalam hal ini yang telah dilakukan Haloa Cafe sudah cukup maksimal dan baik. Dalam proses Engage yang dilakukan Haloa Cafe masih belum maksimal, karena konten yang dibagikan Haloa Cafe masih belum intensif, terlihat dari jumlah like dan comment yang masih sedikit.

\section{Daftar Pustaka}

Bulaeng, A.R. Komunikasi Pemasaran. Jakarta: Universitas Terbuka. 2002.

Saladin, D. Manajemen Pemasaran, Analisis, Perencanaan, Pelaksanaan, dan Pengendalian. Bandung: Lindakarya. 2001.

Kotler, P. Manajemen Pemasaran Analisis, Perencanaan, Implementasi, dan Control. Jakarta: PT Prenhalindo. 1997.
Rochman, E. A., \& Iskandar, B. P. Users' engagement toward the brand accounts in instagram based on the aisas model. Journal of business and management 4 No. 8 (2015): 890-900.

Mustafa, I. Pengguna Instagram di Indonesia Didominasi Wanita dan Generasi Milenial. Agustus 2, 2020.

https://www.goodnewsfromindone sia.id/2020/06/14/penggunainstagram-di-indonesiadidominasi-wanita-dan-generasimilenial

Kota Bandung, Wikipedia Ensiklopedia Bebas. Wikipedia. Juli 29, 2020. https://id.wikipedia.org/wiki/Kota_ Bandung\#Perekonomian.

Tjiptono, F. Strategi Pemasaran, ed. 3. Yogyakarta: 2008.

Aprilya, T. Strategi Komunikasi Pemasaran Melalui Instagran Dalam MeningkatkanKepercayaam Customer Di Samarinda. eJournal Ilmu Komunikasi. 2017.

Kotler, P. Manajemen Pemasaran Analisis, Perencanaan, Implementasi, dan Control. Jakarta: PT Prenhalindo, 1997).

Solomon, M. R. Consumer Behavior and Marketing Strategy. New York: Pearson Prentice Hall, 2011.

Puntoadi, D. Menciptakan Penjualan Melalui Social Media. Jakarta: PT Elex Media Computindo, 2011. 
Luttrell, R. How to engage, Share and connect. London: Rowman \& Littlefield, 2015.

Bungin, Burhan. Penelitian Kualitatif. Jakarta: Kencana Prenada Media Group, 2009.

Creswell, J. W. Esearch Design: Pendekatan Kualitatif, Kuantitatif, Dan Mixed. Yogjakarta: PT Pustaka Pelajar, 2010.

Luttrell, R. How to Engage, Share and Connect. London: Rowman \& Littlefield. 2015. 